Journal of Teacher Education for Sustainability, vol. 20, no. 1, pp. 5-19, 2018

\title{
The Prospects of Transdisciplinary Approach to Promote Learners' Cognitive Interest in Natural Science for Sustainable Development
}

\author{
Inese Jurgena and Dagnija Cēdere \\ University of Latvia, Rìga, Latvia \\ Ingrīda Keviša \\ Academy of Culture, Rìga, Latvia
}

\begin{abstract}
The use of transdisciplinary approach to promote learners' interest in the acquisition of natural science at school provides new opportunities for a complex explanation of the phenomenon and improving the quality of the process of learning. The aim of the study is to explore the learners' cognitive interest, personal participation and the approaches chosen by teachers from the perspective of transdisciplinary approach. The study characterises students' subjective evaluations of their personal participation and cognitive interest in the subjects of biology, chemistry, physics and mathematics, and the approaches used by teachers. The participants were $9^{\text {th }}$ grade students from 17 Latvian schools (536 respondents) with the average age of 15.3 ( $\mathrm{SD}=0.63)$. The results of the study showed that students' evaluations concerning their personal participation in the process of learning were contradictory. They devote little of their free time to the acquisition of science subjects. As to teachers' activity, a variety of teaching approaches are used. According to students' subjective evaluations, the constructivist learning approach corresponds to the trends of sustainable education, whereas the overall context in which the development of learners' cognitive interest in the acquisition of natural science subjects takes place at school highlights issues concerning the sustainable development of the system and the prospects of using the transdisciplinary approach.
\end{abstract}

Keywords: cognitive interest, natural science, personal participation, teaching approach, transdisciplinary approach

\section{The General Context of the Study}

Interest in the transdisciplinary approach to science and education is related to complex and interrelated issues of real world that need to be not only understood, but also resolved in practice, stepping beyond the borders of one field of science.

Science and technology education is closely connected with the development of society; however, many international and national studies reveal the contradiction between the 
increasing societal needs and the insufficient level of young people's education in this field. Interest is one of the components of intrinsic motivation and one of the reasons why students may enjoy learning. What distinguishes it from other sources of enjoyment is that interest is always directed towards an object, activity, a field of knowledge or a goal (OECD, 2016).

Cognitive interest is a complex psychological phenomenon based on the personality characteristics and mental experience in the form of persistent, self-regulated, positively encouraged desire to increase the focus on a specific learning content (Cedere, Jurgena, \& Tarmagadze, 2018). The use of the transdisciplinary approach to solve the burning issues of education and its sustainable development can open new prospects for the understanding and explanation of the complex issue of the development of learners' cognitive interest.

In the context of global challenges, the study of global issues cannot take place within one field of science and one discipline; the concern about the methodological purity of a certain discipline and protecting its boundaries from the potential influence of other disciplines can lead to the self-isolation of the respective discipline regarding knowledge, cooperation and the spread of ideas (Muravska \& Ozolina, 2012).

The studies conducted in the past decades predict important transformations in the system of education. These studies indicate that the space of education is changing dramatically, and it needs a new paradigm (Flogie \& Abrešek, 2015).

Therefore, the need to turn to the transdisciplinary approach for the sustainable development of education has emerged as a possible solution that can provide a new open perspective for the understanding and interpretation of the complex phenomenon of sustainability. "The need to focus on a transdisciplinary approach in education for sustainable development (ESD) has been reflected in research and especially action research as a possible solution, which can open a new perspective for understanding and interpretation of the complex phenomenon of sustainability as well as for developing new open continuing education programmes by integrating research and learning activities in the context of open transdisciplinary research" (Salite et al., 2016, p. 135).

What sets transdisciplinarity apart from other approaches, and what assures its role in the twenty first-century education is its acceptance of and its focus on the inherent complexity of reality that is seen when one examines a problem or phenomenon from multiple angles and dimensions with a view toward "discovering hidden connections between different disciplines" (Madni, 2007, p. 3).

The current approach of transdisciplinarity is characterised by three key discourses: transcendence, problem solving, and transgression. According to Klein, the main epistemological idea of the discourse of transcendence is the idea of unity, which is rooted in Ancient Greece in the West. The emerging of transdisciplinarity implies the need for a new synthesis resulting from the increasing fragmentation of knowledge and culture (Klein, 2015).

In Ancient Greece knowledge was not limited to a definite discipline, and the leading scholars could freely engage in various fields of knowledge. Because of reductionism, which began with Aristotle and lasted until the end of the previous millennium, a lot of separate disciplines emerged with strictly set boundaries (Bregant, Stožer, \& Cervenik, 2010). Aristotle's idea of phronesis, which has not been fully understood and used in education, is also important in this respect (Salīte, Gedžūne, \& Gedžūne, 2009). 
The issues resulting from the crisis of sustainability and the global environment brought transdisciplinarity to the foreground again in the 1990s within the context of reforms in higher education (Klein, 2001, 2015).

Transdisciplinarity re-emerged in the 1990 s as an urgent issue related to the solution of new, highly complex, global concerns, beginning with climate change and sustainability and extending into many areas concerning science, technology, social problems and policy, education and the arts. Transdisciplinarity today is characterized by its focus on complex problems that need creative solutions, its reliance on stakeholder involvement, and engaged, socially responsible science (Bernstein, 2015). This underlying assumption is also used by other scholars when explaining the transdisciplinary approach (Pipere, 2016; Salìte, Drelinga, Iliško, Oḷehnoviča \& Zarina, 2016).

Several scholars suggest that the transdisciplinary approach reflects changes in the way how we think about education challenging the division of academic labour into traditional disciplines.

The advent and development of transdisciplinarity demonstrate emerging ways not only of organising, but also of thinking about knowledge and inquiry in a world that has become "too big to know" (Weinberger, 2011). As Alfonso Montuori (2008) writes in his foreword to a recent book on the subject, transdisciplinarity is perhaps a new way of thinking about and engaging in inquiry.

Scholars suggest that the issues concerning the sustainability of education could be solved using the paradigm of complexity, which requires more complex and comprehensive views, and, consequently, a new vison of the world and a new interpretation of the world (Pipere, 2016). The experience of the activity of BBCC (Baltic and Black Sea Circle Consortium) as the development of a complex system and process also shows how, focusing on evolution in cooperation relationships, it is possible to find answers that enable the reorientation of teacher education to sustainable development (Salite, 2015).

Transdisciplinarity does not have one certain definition encompassing all its diverse manifestations. Therefore, it is important to analyse the ideas of various scholars concerning their understanding of transdisciplinarity.

The word "transdisciplinarity" was introduced in 1970 at a seminar on interdisciplinarity in universities held at the University of Nice. The eminent Swiss psychologist Jean Piaget is generally credited with coining the term (Lopez-Huertas, 2013; Nicolescu, 2010; Padurean \& Cheveresan, 2010). The conclusion of Piaget's (1972) essay on various kinds of interaction between the disciplines mentions transdisciplinarity offhand, as a "higher stage succeeding interdisciplinary relationships ... which would not only cover interactions or reciprocities between specialised research projects but would also place these relationships within a total system without any firm boundaries between disciplines" (Piaget, 1972, p. 138).

Nicolescu gave a more precise definition of transdisciplinarity by pointing out that "transdisciplinarity concerns that which is at once between the disciplines, across the different disciplines, and beyond all disciplines. Its goal is the understanding of the present world, of which one of the imperatives is the unity of knowledge" (Nicolescu, 2010, p. 22).

Nicolescu's contribution to the understanding of transdisciplinarity and philosophy has been highly evaluated by Sue McGregor, who suggests that "Nicolescu concerns himself with the meaning of going beyond disciplines and asserts that, transdisciplinarity 
identifies with a new knowledge about what is between, across, and beyond disciplines" (McGregor, 2015). Indeed, Nicolescu developed a completely new and universal methodology to create new knowledge and solve complex problems.

The scholars belonging to Zurich school highlighted the importance of transdisciplinarity in solving real world problems and the interconnectedness of science, society and technologies in the world today (Tejedor \& Segalas, 2013).

Unfortunately, education has focused on the multidisciplinary approach so far, which envisages considerable autonomy for each discipline (Salite et al., 2016). A vivid example is the fact that natural science is divided into the subjects of physics, chemistry and biology in our schools.

Nowadays, it is no longer sufficient that learners acquire knowledge and skills in separate subjects; they also need more experience in using them and the tools for solving problems in their daily lives. There are no separate disciplines in real life; the ability to act and solve problems is based on the integration of knowledge and skills or their merging in a definite life situation with a definite purpose at a definite moment. It means that the new paradigm of education should rise at a higher level. Therefore, it is necessary to consider transdisciplinarity in the process of teaching/learning, which means exploring some real-life problems and integrating the views of several disciplines on it, so that learners could relate their new knowledge and deeper understanding to real-life experience.

In the context of sustainability, the new strategy in science education can be characterised as a "socio-scientific issues-based approach", which is focused on the development of critical thinking skills and learners' understanding of the real world based on inventions and innovations in science and technology that affect their lives (Eilks, 2015). Scholars use the transdisciplinary approach to offer complex models for the implementation of education reforms.

In the context of our study, an interesting example is the model of cognitive neuroeducation, which blends neuroscience, cognitive science, education and other related sciences to create a new transdisciplinary field, encompassing all the research related to the process of learning, and break the intellectual walls separating these disciplines (Flogie, Dolonec, \& Aberšek, 2015).

This model highlights two important premises: first, the process of teaching and learning should start with neuroscience; second, it is important to consider the way how the human brain acquires and processes information. Besides, the possibilities of creating an appropriate learning environment should be considered because the needs of education must always be perceived in a complex way; its content, teaching methods, learning environment, and the organization of the process of education are always intertwined. As we know, the mission of education is to experience what has been learned in a qualitative transition from declarative knowledge to the knowledge of experience, and from knowledge in the broader meaning of this word to useful competencies (Flogie \& Aberšek, 2015).

The results of research conducted in several European countries reveal the signs of unsustainability in the process of learning since traditional approaches do not always promote leaners' interest in the subjects of natural science mainly because they do not see a link between science, real life, their personal interests and participation in the process of learning.

Lack of interest in natural science is an old issue, and it still exists (Cedere, Jurgena, \& Targamadze, 2018; Potvin \& Hasni, 2014; Sjoberg \& Schreiner, 2010). According to 
Osborne (2014), natural science education does not always achieve its planned goals because learners lack interest in these subjects. Our previous studies also imply a low level of interest among $9^{\text {th }}$ grade students regarding natural science subjects and mathematics (Cedere, Jurgena, \& Gedrovics, 2015; Cedere, Jurgena, \& Praulite, 2016). Only one fifth of the Latvian $9^{\text {th }}$ grade students demonstrate a high level of cognitive interest (Cedere, Jurgena, Helmane, Tiltina-Kapele, \& Praulite, 2015).

The studies mentioned above indicate that there are problems concerning the development of learners' cognitive interest; therefore, according to the principles of complex adaptive systems, to get a more complete picture of the real situation, it is necessary to overcome dualism (teaching versus learning, cognitive versus affective, and a learner versus a teacher), and consider phenomena from different angles taking contextual factors into account (Briede, 2015).

It is important to be aware of the sociological context in which 9th grade students obtain education. Based on the studies of generational characteristics, scholars have concluded that Generation $\mathrm{Z}$ is the first generation raised in an uncertain and complicated global environment, in the world of developed information and communication technologies (ICT), where a different kind of information processing prevails. At present, the communication of $70 \%$ of the students is affected by its visual character (McCrindle, 2014); the internet has paved the way for Pxts (picture texts), where words have been replaced by symbols or universal icons (McCrindle, 2014). The means provided by ICT are natural tools for Generation Z, and they have an impact on how they understand the world, how they learn and communicate, and what kind of priorities they have. Young people can process information, but they often do not perceive the context in which this information should be interpreted (Mladkova, 2017).

The boundaries of using digital media are constantly expanding for Generation Z, and their culture of learning has changed. By expanding the virtual learning space, it should be considered that the technologies used will also affect the cognitive, social and emotional development of learners (Lee \& Choi, 2017; Underwood \& Farrington-Flint, 2015). It is pointed out in several studies that pedagogically justified use of technologies promotes active learning as it arouses interest, accelerates the working process and allows students to engage in the process of learning more actively compared to the traditional approach (All, Plovic, Patricia, Castella, \& Looy, 2017; Barr, Pennycook, Stolz, \& Fugelsang, 2015; Volk, Cotič, Zajac, \& Starcic, 2017). At the same time, it is important to be aware that, constantly working with images in the digital environment, learners develop the so-called "clip thinking", a short-term memory (Lee \& Choi, 2017; McCrindle, 2014, p. 154). Moreover, the feeling of loneliness increases, and active participation in group work activities decreases (Dincer \& Doganay, 2017).

The efficient use of ICT in learning science subjects makes it possible to enhance the effectiveness of education and create a more up-to-date and attractive learning environment. The supporters of the integrated approach suggest that teaching science subjects in the context of real-life problems can make the content of learning more relevant to students, which can help increase their motivation, generate interest and improve learning results (Honey, Pearson, \& Schweingruber, 2014; Lamanauskas, 2011). Undoubtedly, teachers' professionalism and the change of their teaching paradigm play the key role in the development of the new politics of education (Flogie, Dolenc, \& Aberšek, 2015). Scholars put particular emphasis on the role of e-learning, which changes the possibilities of learning (Kapenieks, 2016; Kapenieks \& Salite, 2012). 
The aim of the study is to explore the learners' cognitive interest, personal participation and the approaches chosen by teachers according to students' subjective assessment.

\section{Methods}

\section{Instruments}

The data analysed in the present article were obtained in the study carried out in the period of 2015-2017. The survey used in the study characterises students' subjective evaluations of the correlation between their personal participation and cognitive interest in the subjects of biology, chemistry, physics and mathematics, and the approaches used by teachers in the process of learning. The survey was designed based on the studies performed earlier (Cedere, Jurgena, Helmane, Tiltina-Kapele, \& Praulìte, 2015) and documents regulating education in Latvia (Latvijas Republikas Ministru kabinets, 2013); as well as the teaching methods recommended by the National Centre for Education (Valsts izglitibas satura centrs) were included in the survey. The survey was focused on students' understanding of the importance of the knowledge and skills related to natural science in real life. It enabled the authors of the study to clarify how the learners evaluate their cognitive interest in natural science subjects and mathematics, and how they understand the nature of science, which their main areas of interest are, and which methods are the most helpful in their learning. The survey included both open-ended and closed items. The four-point Likert scale was used for fixed response items, with responses ranging from 1 'no' to 4 'yes'.

Cronbach alpha was used to establish the reliability of the survey. According to Cronbach's alpha coefficient, the reliability (inter-item consistency) of the questionnaire was 0.91 .

The mean values of the responses $\mathrm{M}(1 \leq \mathrm{M} \leq 4)$ and standard deviations (SD) were used to characterise the answers given by the respondents.

\section{Participants and Procedure}

The participants of the survey were $9^{\text {th }}$ grade students from 17 Latvian schools with the total number of respondents 536 . The average age of the respondents was 15.3 $(\mathrm{SD}=0.63)$.

The survey was prepared online, using the Google disc, and the respondents also completed the survey online. All the respondents participated in the survey voluntarily. The responses were anonymous; the data were used only in a processed form.

\section{Results of Research}

By means of the survey, there were obtained data characterising learners' attitude to natural science subjects and the process of learning in general - the approaches used by teachers and students' involvement in the process of learning in the context of transdisciplinarity.

The results of the student survey showed that cognitive interest in the subjects of natural science was not high (see Fig. 1). Figure 1 shows that the students like biology lessons most of all $(\mathrm{M}=2.89)$, which means that the average response chosen by the 
respondents is mostly yes. The average response concerning interest in the other three subjects was between mostly no and mostly yes.

Looking at the distribution of the responses (Fig. 2), it appears that very few students do not like biology, but the opinion is mixed about mathematics - a significant number of those surveyed have a negative attitude, but most of the respondents like it. The number of the positive responses (yes and mostly yes) was the following: biology $36.4 \%$ and $27.8 \%$, chemistry $-28.4 \%$ and $18.2 \%$, physics $-33.6 \%$ and $20.1 \%$ and mathematics $-30.5 \%$ and $26.8 \%$ of the respondents. Consequently, most of those surveyed gladly study natural science and mathematics, and they do not experience significant difficulties studying them, but the fact that almost a half of the samples have no interest in studying these subjects (answers no and mostly no) is alarming. The respondents' comments imply that the students believe they will not need natural science in their lives, and these subjects "do not come easy" to them.

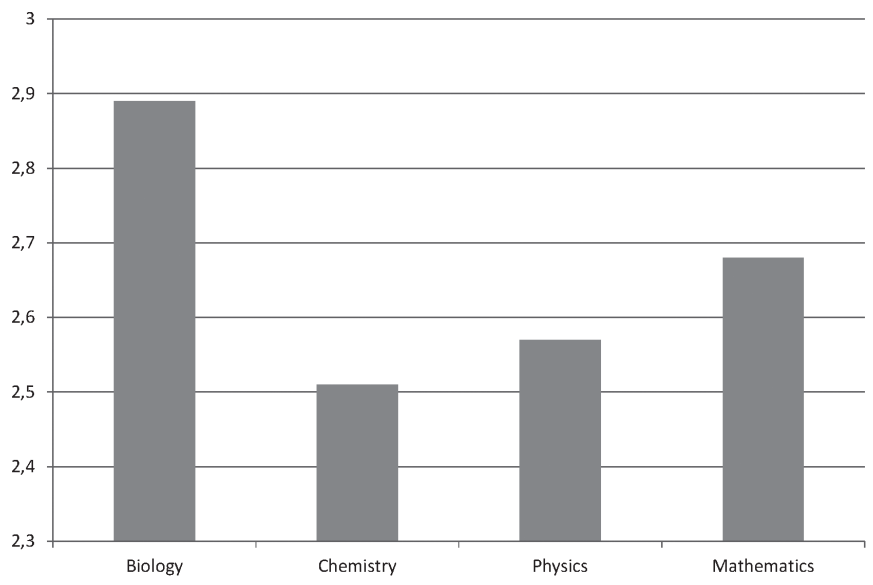

Figure 1. Students' interest in studying natural science and mathematics, the mean values of the responses $(\mathrm{N}=536)$

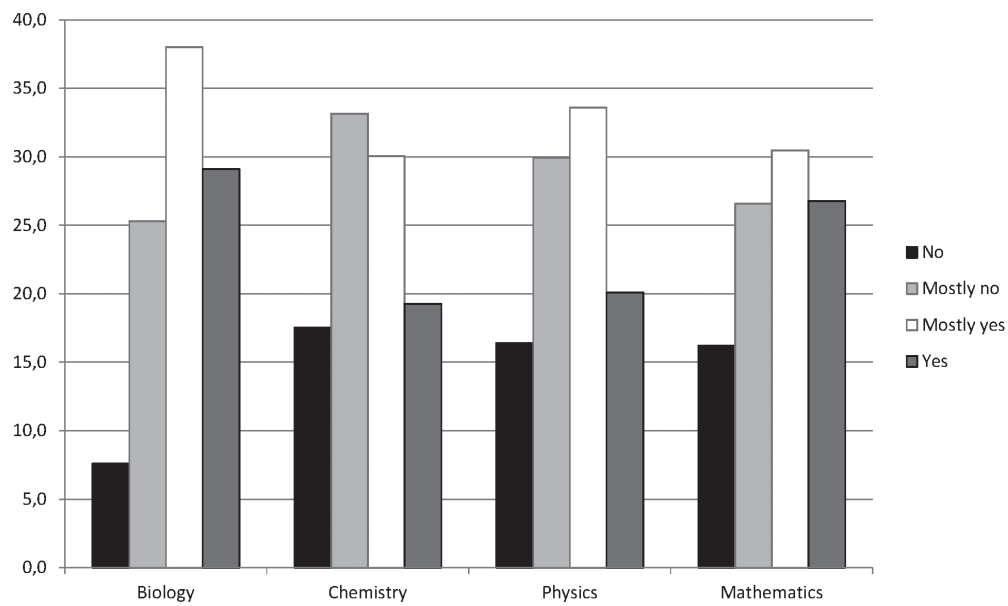

Figure 2. Distribution of the students' responses regarding their interest in studying natural science and mathematics $(\mathrm{N}=536)$ 
To characterise students' interest in natural science, the mean values $(\mathrm{M})$ of the most characteristic responses and their standard deviations (SD) are summarised in Table 1. It appears that the students have a relatively high interest in natural phenomena (rain, thunderstorm, volcanoes, etc.) and the willingness to explain them $(\mathrm{M}=2.96)$. The desire to discover the causes of natural phenomena and processes $(\mathrm{M}=2.81)$ or analyse real-life problems within the context of natural science $(\mathrm{M}=2.81)$ appears to be lower. Students' interest in solving such problems decreases when mathematical calculations need to be used to solve them $(\mathrm{M}=2.12)$. The responses to the question whether their leisure time is related to natural science show the lowest mean value $(\mathrm{M}=1.91$ and 1.90).

Table 1

Students' Interest in Natural Science Ranked According to the Mean Values of the Responses $(\mathrm{N}=536)$

\begin{tabular}{clcc}
\hline Code & \multicolumn{1}{c}{ Items } & M & SD \\
\hline A4 & Explaining natural phenomena & 2.96 & 0.81 \\
\hline A5 & Finding out the causes of natural phenomena & 2.81 & 0.79 \\
\hline A6 & Analysing problems related to the real life & 2.76 & 0.88 \\
\hline A9 & Enthusiasm for natural science & 2.57 & 1.04 \\
\hline B11 & Exploration of relationships of math with real life problems & 2.23 & 1.13 \\
\hline B13 & The use of maths in solving practical tasks & 2.16 & 1.13 \\
\hline A14 & Devoting the leisure time to science exploration & 1.91 & 0.96 \\
\hline A8 & Exploration of nature outside the school & 1.90 & 1.02 \\
\hline
\end{tabular}

The second group of items shows the teaching methods which helped the students most in learning science subjects. The survey included various kinds of teaching methods practiced in Latvian schools (Valsts izglitîbas satura centrs). The methods used in teaching mathematics are specific, and they are not included in the study. The responses concerning the teaching methods that were reported as the most helpful ones for the acquisition of natural science subjects are summarised in Table 2.

Table 2

Students' Assessment of Teaching Methods Used in Natural Science Subjects Ranked According to the Mean Values of the Responses ( $N=536)$

\begin{tabular}{clcc}
\hline Code & \multicolumn{1}{c}{ Methods } & M & SD \\
\hline C2 & Demonstrations & 3.55 & .82 \\
\hline C5 & Laboratory work & 3.39 & .87 \\
\hline C4 & Questions and answers & 3.33 & .88 \\
\hline C3 & Discussion & 3.29 & .93 \\
\hline C12 & Teacher's lecturing & 3.21 & .95 \\
\hline C6 & Laboratory research work & 3.19 & 1.00 \\
\hline C15 & Using visual aids & 3.13 & 1.01 \\
\hline C9 & Problem solving & 3.03 & .99 \\
\hline C10 & Case study & 3.02 & .99 \\
\hline C16 & Making visual aids & 2.81 & 1.05 \\
\hline
\end{tabular}


Thus, demonstrations performed by a teacher appear to have been more helpful than laboratory work where learners must perform experiments themselves $(M=3.55$ and $M=3.29$, respectively). Active students' participation in the process of learning is known to be more productive than passive observation, but the results of the study imply the opposite. It could be because the students had performed laboratory experiments so seldom that the contribution of laboratory work to their learning was negligible. The post-survey comments confirm this assumption. A lot of students pointed out that there should be more laboratory work in physics and chemistry, and then the lessons would be more interesting. In general, all the teaching methods characteristic of natural science are regarded as useful by the respondents. Nevertheless, the methods requiring more effort showed lower values than simple laboratory work $(M=3.39$ and $M=3.19)$, problem solving $(M=3.03)$ and case study $(M=3.02)$. Analysing students' post-survey comments, another reason appears - these methods are used in class so seldom that they do not help students much in acquiring the content of learning.

It can be concluded that teacher's activity dominates in the lessons of natural science, which is also confirmed by respondents' comments, and students' activity in the lessons is rather low. Consequently, the schools are not ready for the transition to the transdisciplinary approach, so a radical methodological change and a different approach are needed, which teachers must be prepared and trained for.

Students' interest in cognizing and exploring various phenomena related to nature and everyday life, analysing and establishing the causes of various problems allows using various teaching approaches. In general, students appreciated the teaching methods used in class, but they also admitted that they had no interest in these subjects (except for biology). It means that although teachers use various methodological techniques, and students are given opportunities to acquire the kinds of cognition characteristic of natural science and develop their skills in accordance with the school curriculum, a broader contextual solution is necessary for promoting students' cognitive interest.

Respondents' post-survey comments showed the diversity of students' views. Most of them understood the nature of science and recognised the importance of these subjects. The following comment written by a respondent illustrates it very well: "Biology, chemistry and physics are very interesting subjects. In these lessons, we can learn a lot of new things about the world around us and the objects and phenomena we encounter in our daily lives." Some comments imply students' willingness to learn more actively and engage in practical learning activities, for instance: "The lessons should be more interesting, not just sitting and calculating"; "I'd like to have more experiments in class to make the lessons more interesting and easier to understand"; "There should be more laboratory work in chemistry and physics." The number of students expressing the opposite opinion is smaller: "I don't like physics and chemistry very much"; "I hate natural science..."; "I don't understand why we should study natural science and mathematics more than art and music. I'm not good at chemistry and physics, but I'm good at arts...”.

Students' post-survey comments imply that most students lack confidence in their abilities, the capacity of self-reflection, the desire to be successful and the confidence in their ability to succeed: “There shouldn't be any homework..."; "We shouldn't be required to learn what does not come easy to us"; "I'm not good at chemistry and physics, but I'm good at arts...”. These responses only confirmed the lack of cognitive interest established above and learners' unwillingness to delve into the topic to understand it. 


\section{Discussion}

The study concerns some aspects of the transdisciplinary approach and gives an insight in the views of $9^{\text {th }}$ grade students concerning natural science and their formation in contemporary schools.

As to the question which teaching methods are most helpful for students in their learning, the study provides additional arguments for the discussion why demonstrations performed by the teacher where learners are passive observers appear to be more helpful than the experiments performed by students. The study identified the need for changing the teaching approaches, which also corresponded to the conclusions given in academic literature (Krapp \& Prenzel, 2011; McCrindle, 2014; Osborne, 2014; Pešakovičs, Flogie, \& Aberšek, 2014, etc.).

It is important to understand the sociological context within which the 9th form students obtain education. According to the studies of generational characteristics, Generation $\mathrm{Z}$ is the first generation raised in the uncertain and complicated global environment, in the world of developed ICT technologies, where a different way of information processing predominates. The boundaries of using digital media are constantly expanding for Generation Z, and their learning culture has changed. Broadening the virtual learning space, it should be considered that the technologies used at the same time will have a different impact on the cognitive, social and emotional development of learners (Lee \& Choi, 2017; Underwood \& Farrington-Flint, 2015).

The study clearly demonstrates that students are interested in solving real problems, whereas lessons in science subjects do not give them satisfaction, and a large number of the students do not regard natural science as useful for them. To make learning productive, it is necessary to adopt the transdisciplinary approach in the process of learning/ teaching, which means exploring some important real-world issues or situations by integrating the perspectives of various disciplines (Flogie \& Aberšek, 2015; Lee \& Choi, 2017).

These contexts expand the field of learning, and they have the potential of deepening learning; at the same time, they can cause problems for learners. For instance, there is evidence (Honey, Pearson, \& Schweingruber, 2014) that, using detailed, specific situations including the abundant development of perception, learners cannot identify abstract structural characteristics necessary to transfer their experience to another situation.

Regarding the low rating given for the methods requiring effort and learners' active participation, it is important to understand students' motivation and goals. They include not only the desire for success, but also the desire of avoidance. It can be a challenge for educators. As to the students whose motivation is not so highly developed, or whose motivation is avoidance, the change of pedagogical approaches alone will not give the desired result. At present, the schools put emphasis on identifying mistakes, which stimulates the avoidance strategy and affects students' choices - to study those subjects that come easier to them and to resist the learning activities where they need to concentrate their attention for a long time, put in effort, and where positive results cannot be achieved soon (Cedere, Jurgena, \& Kalnina, 2017; Jurgena, Cedere, \& Keviša, 2015; Migdley \& Urdan, 2001).

From our perspective, students' subjective opinions on the factors that cause interest in some subject or learning method is the issue concerning learners' self-determination. 
In the contemporary society of internationalized and technologized production and services, there is a need for new abilities, which brings the notions of learners" "selforganization", "self-regulation" and "self-responsibility" to the foreground. Special attention is paid to the subject, i.e., a human being consciously engaged in certain activity. "Focusing on a subject" is a general trend (Hozkamp, 1995, p. 5).

At present, the opinion dominant in the school practice suggests that the process of learning should be organized in a different way, but it does not provide a complex solution to the problem because, from subject's perspective, learning cannot be reduced to the organization of the process of learning, especially if it is determined from the outside. Learning cannot be reduced to the methods of learning either. It involves much more than the act of learning itself. It starts with dividing the object of learning into constituent parts done by the subject and setting learning goals. A teacher cannot demonstrate it to learners; it is done by the subjects of learning. This understanding of learning requires the subjective reason for learning/not learning and puts emphasis on individual's participation.

Therefore, regarding students' learning, it is necessary to speak not only about content, but also about learning strategies. Each discipline has corresponding learning methods. Finding a method that fits both the object and the person is a specific learning objective. It is the problem concerning learner's activity that can only be solved by learning. The subject of learning does not necessarily have to use the offered special didactics or psychological learning theories. Individual learning methods and techniques can be developed and used equally well. Besides, each learner has his/her own learning experience based on which certain learning interests have been formed and generalized (Helds, 2006).

It agrees with the studies suggesting that certain incomprehension (Flogie, Dolonec, \& Aberšek, 2015) and dualism (Briede, 2015) can be observed in the school practice concerning the organization of the process of teaching/learning nowadays. It actualizes the need for using the transdisciplinary approach.

\section{The Limitations of the Study}

As the empirical study concerns the opinions of the Latvian 9th grade students about the development of cognitive interest in the acquisition of natural science subjects, the authors of the article do not attempt to evaluate and interpret the results of the study in a broader context.

The study reveals the opinions of the 9th grade students at the institutions of general education, and it can be used as the basis for further research concerning the implementation of the transdisciplinary approach in school practice. The results of the study imply that it is necessary to conduct further studies and set the directions of practical activity - to conduct an international comparative study to evaluate and adopt the models of best practice.

A lot of students are willing for more interesting lessons, which depends not only on teacher's professionalism, but also on the material and technical possibilities of the school. Judging from students' comments, the lessons are often monotonous, and the students are not actively involved in the process of learning. Unfortunately, this is the current situation. Regularly faced with students' indifference and unwillingness to learn, on the one hand, and the low prestige of their profession in society, on the other hand, 
a lot of teachers develop a formal attitude to their job. It seems questionable whether these teachers should call themselves pedagogues.

\section{Conclusions}

The study shows the complex interaction of three phenomena - learner's cognitive interest, personal participation and the approaches used by a teacher. The present research provides a new perspective and an opportunity for the study of the phenomenon of sustainability from the wider angle of the interaction of various processes, which will require a holistic (transdisciplinary) view on the development of complex phenomena and their interaction in the acquisition of natural science subjects at school.

It is difficult to evaluate the development of learners' cognitive interest in studying natural science subjects at school and its interconnection with learners' personal participation and the approaches chosen by teachers due to the complex structure of these phenomena. Nevertheless, there is a relationship between learner's cognitive interest, personal participation and the approach chosen by the teacher.

According to students' subjective evaluations, the approach focused on teaching constructivism corresponds to the trends of sustainable education, but the overall context where the development of students' personalities takes place indicates that the system experiences problems with regard to its sustainable development, and the transdisciplinary approach could potentially be used to understand the specific features of the development of learners' cognitive interest in studying natural science subjects at school.

It can be concluded that the students have the potential for interest necessary to understand the nature of science and acquire the knowledge and skills important for their future lives. It is necessary to look for new, appropriate methodological techniques. Using the transdisciplinary approach, the students would form the notion of the material world based on interconnected knowledge as the foundation for future scientific cognition.

\section{References}

All, A., Plovie, B., Nuriez Castellar, E. P., \& Van Looy, J. (2017). Pre-test influences on the effectiveness of digital-game based learning: A case study of a fire safety game. Computers \& Education, 114, 11, 24-37.

Badura, A. (1986). Social foundations of thought and action: A social cognitive theory. Englewood Cliffs, NJ: Prentice Hall.

Barr, N., Pennycook, G., Stolz, J. A., \& Fugelsang J. A. (2015). The brain in your pocket: Evidence that smartphones are used to supplant thinking. Computers in Human Behaviour, 48, 473-480.

Bernstein, J. H. (2015). Transdisciplinarity: A review of its origins, development, and current issues. Journal of Research Practice, 11(1), Article R 1.

Bregant, I., Stožer, A., \& Cerkvenik, M. (2010). Molecular reduction: reality or fiction? Synthese, 72(30), 437-450.

Briede, L. (2015). The relationship between mathematics teachers teaching approaches and 9th grade students mathematical self [Doctoral dissertation], Daugavpils: Daugavpils University.

Bybee, R. W. (2013). The case for STEM education: Challenges and opportunities. Arlington, VA: National Science Teachers Association. 
Cedere, D., Jurgena, I., \& Gedrovics, J. (2015). Longitudinal research on the change of Grade 9 pupils' cognitive interests in sciences (2003-2013). In V. Dislere (Ed.), Engineering for Rural Development. Proceedings of the 14th International Scientific Conference (pp. 742-747). Jelgava: Latvia University of Agriculture.

Cedere, D., Jurgena, I., Helmane I., Tiltina-Kapele, I., \& Praulīte, G. (2015). Cognitive interest: problems and solutions in the acquisition of science and mathematics in schools of Latvia. Journal of Baltic Science Education, 14(4), 424-434.

Cedere, D., Jurgena, I., \& Kalnina S. (2017). Prospective teachers' opinion about the content of modern basic education in the science context. In V. Dislere (Ed.), Rural Environment, Education, Personality. Proceedings of the 10th International Scientific Conference (pp. 63-69). Jelgava: Latvia University of Agriculture.

Cedere, D., Jurgena, I., \& Praulite, G. (2016). Possibilities of promoting students' cognitive interest in science subjects. In V. Dislere (Ed.), Engineering for Rural Development. Proceedings of the 15th International Scientific Conference (pp. 511516). Jelgava: Latvia University of Agriculture.

Cedere, D., Jurgena, I., \& Targamadze, V. (2018). Interest of Latvian and Lithuanian students in science and mathematics. Journal of Baltic Science Education, 17(1), 31-42.

Dincer, S., \& Doganay, A. (2017). The effects of multiple-pedagogical agents on learners' academic success, motivation, and cognitive load. Computers \& Education, 111, 74-100.

Eilks, I. (2015). Science education and education for sustainable development - justifications, models, practices and perspectives. Eurasia Journal of Mathematics, Science \& Technology Education, 11(1), 149-158.

Flogie, A., \& Aberšek, B. (2015). Transdisciplinary approach of science technology, engineering and mathematics education. Journal of Baltic Science Education, 14(6), 779-789.

Flogie, A., Dolonec, K., \& Aberšek, B. (2015). Transdisciplinarity in education is near. In V. Lamanauskas, V. Šlekiené, \& I. Raguliené (Eds.), State-of-the art and future perspectives. Proceedings of the 11th International Baltic Symposium on Science and Technology Education (BalticSTE2015) (pp. 45-47). Šiauliai: Scientia Socialis Press.

Helds, J. (2006). Mācīšanās kā konstruktīvs un sistēmisks jēdziens [Learning as a constructive and systemic notion]. In I. Maslo (Ed.), No zināšanām uz kompetentu darbibu [From knowledge to competent activity] (pp. 31-44). Rīga: LU Akadēmiskais apgāds.

Holzkamp, K. (1995). Lernen. Subjektwissenschaftliche Grundlegung. Frankfurt: Studienausgabe.

Honey, M., Pearson, G., \& Schweingruber, H. (Eds.) (2014). STEM integration in K-12 education: Status, prospects, and an agenda for research. Washington, D.C.: The National Academies Press. Retrieved from http://www.nap.edu/catalog.php? record_id=18612

Jihyun, L., \& Hyoseon, C. (2017). What affects learners' higher-order thinking in technology-enhanced learning environments? The effects of learner factors. Computers \& Education, 115(12), 143-152.

Jurgena, I., Cedere, D., \& Keviša I. (2015). Innovative and traditional elements in the work of academic staff: The views of pre-service teachers. Journal of Teacher Education for Sustainability, 17(2), 74-90. 
Kapenieks, J., \& Salite, I. (2012). Action research for creating knowledge in an e-learning environment. Journal of Teacher Education for Sustainability, 14(2), 111-129.

Kapenieks, J. (2016). Educational action research to achieve the essential competencies of the future. Journal of Teacher Education for Sustainability, 18(1), 95-110.

Klein, J. T. (2015). Reprint of 'Discourses of transdisciplinarity: Looking back to the future.' Futures, 65, 10-16.

Klein, J. T. (2001). The discourse on transdisciplinarity: An expanding global field. In J. Thompson Klein, W. Grossenbacher-Mansury, R. Hāberli, A. Bill, R. W. Scholz, \& M. Welti (Eds.), Transdisciplinarity: Joint problem solving among science, technology, and society: An effective way of managing complexity (pp. 35-45), Basel, Switzerland: Birkhāuser.

Lamanauskas, V. (2011). Ten theses on modern natural science education. Problems of Education in the 21st Century, 33, 5-8.

Lopez-Huertas, M. (2013). Reflexions on multidimensional knowledge: Its influence on the Foundation of knowledge organization. Knowledge Organization, 40(6), 400-407.

Madni, A. M. (2007). Transdisciplinarity: Reaching beyond disciplines to find connections. Journal of Integrated Design and Process Science, 11(1), 1-11.

McCrindle, M. (2014). The ABC of XYZ. McCrindle Research Pty Ltd.

McGregor, S. L. T. (2015). The Nicolescuian and Zurich approaches to transdisciplinarity. Integral Leadership Review, 15(2), 6-16.

Migdley, C., \& Urdan, T. (2001). Academic self-handicapping and performance goals: A further examination. Contemporary Educational Psychology, 26, 61-75.

Mladkova, L. (2017). Learning habits of generation Z students. Proceedings of the European Conference on Knowledge Management, ECKM, 2, 698-703.

Montuori, A. (2008). Foreword: Transdisciplinarity. In B. Nicolescu (Ed.), Transdisciplinarity: Theory and Practice (pp. 9-17). Cresskill, NJ: Hampton.

Muravska, T., \& Ozoliṇa, Ž. (Eds.) (2012). Starpdisciplinaritāte sociālajās zinātnēs: vai tā sniedz atbildes uz mūsdienu izaicinājumiem augstākajā izglìtībà un pētniecībā [Transdisciplinarity in social sciences: does it provide answers to contemporary challenges in higher education and research]? Rīga: LU Akadēmiskais apgāds.

Nicolescu, B. (2010). Methodology of transdisciplinarity - Levels of Reality, Logic of the Included Middle and Complexity. Transdisciplinary Journal of Engineering \& Science, 1(1), 19-38.

OECD (2016). PISA 2015 Results (Volume I): Excellence and Equity in Education. Paris: PISA, OECD Publishing. Retrieved from http://dx.doi.org/10.1787/9789264266490-en

Osborne, J. (2014). Teaching scientific practices: Meeting the challenge of change. International Journal of Science Education, 25(2), 177-196.

Padurean, A., \& Cheveresan, C. T. (2010). Transdisciplinarity in education. Journal Plus Education, 6(1), 127-133.

Pešakovič, D., Flogie, A., \& Aberšek, B. (2014). Development and evaluation of a competence-based teaching process for science and technology education, Journal of Baltic Science Education, 13(50), 740-755.

Piaget, J. (1972). The epistemology of interdisciplinary relationships. In Centre for Educational Research and Innovation (CERI), Interdisciplinarity: Problems of Teaching and research in universities, Paris: Organisation for Economic Co-operation and Development, 127-139. 
Pipere, A. (2016). Envisioning complexity: Towards a new conceptualization of educational research for sustainability. Discourse and Communication for Sustainable Education, 7(2), 68-91.

Potvin, P., \& Hasni, A. (2014). Interest, motivation and attitude towards science and technology at K-12 levels: a systematic review of 12 years of educational research. Studies in Science Education, 50(1), 85-129.

Salite, I. (2015). Searching for sustainability in teacher education and educational research: Experiences from the Baltic and Black Sea Circle Consortium for Educational Research. Journal of Teacher Education for Sustainability, 6(1), 21-29.

Salite, I., Drelinga, E., Iliško, Dz., Oḷehnoviča, E., \& Zariņa, S. (2016). Sustainability from the transdisciplinary perspective: An action research strategy for continuing education program development. Journal of Teacher Education for Sustainability, $18(2), 135-152$.

Salīte, I., Gedžūne, G. \& Gedžūne, I. (2009). Educational action research for sustainability: Seeking wisdom of insight in teacher education. Journal of Teacher Education for Sustainability, 11(2), 14-30.

Sjøberg, S., \& Schreiner, C. (2010). The ROSE project. An overview and key findings. Retrieved from https://roseproject.no/network/countries/norway/eng/nor-SjobergSchreiner-overview-2010.pdf

Latvijas Republikas Ministru kabinets [The Cabinet of Ministers of the Republic of Latvia] (2013). Noteikumi par valsts pamatizglitibas standartu, pamatizglitības mācību priekšmetu standartiem un pamatizglìtības programmu paraugiem [Regulations on national standard of basic education, subject standards of basic education and sample basic education curricula]. Retrieved from http://likumi.lv/ doc.php?id=259125

Underwool, J. D. M., \& Farrington-Flint, L. (2015). Learning and the e-generation. West Sussex: Wiley, Blackwell.

Weinberger, D. (2011). Too big to know: Rethinking knowledge now that the facts aren't the facts, experts are everywhere, and the smartest person in the room is the room. New York, NY: Basic.

Valsts izglìtíbas satura centrs [National Centre for Education]. Mācību priekšmetu programmu paraugi pamatizglìtīb $\bar{a}$ [Samples of subject curricula in primary education]. Retrieved from http://www.visc.gov.lv/vispizglitiba/saturs/programmas_pam_ izgl.shtml

Volk, M., Cotič, M., Zajc, M., \& Istenic Starcic, A. (2017). Tablet-based cross-curricular maths vs. traditional maths classroom practice for higher-order learning outcomes, Computers \& Education, 114, 11, 1-23.

Correspondence concerning this paper should be addressed to Dr. paed. Inese Jurgena, Faculty of Education, Psychology and Art, University of Latvia, Imantas linija 7/1 str, LV-1083, Riga, Latvia. Email: inese.jurgena@lu.lv 